\title{
Personals / Carrière et emploi
}

\section{Harvey Anderson awarded a CIF/IFC Fellow membership}

The Canadian Institute of Forestry/Institute forestier du Canada (CIF/IFC) Board of Directors recently recognized Harvey Anderson's contribution for forestry, by awarding him with a CIF/IFC Fellow membership. His personal contributions to the practice of forestry in Ontario, both as a scientist and teacher have been exceptional.

Harvey's research career and continuing efforts as an active public educator through the Southern Ontario Section's Kortright Project have led the way in moving the understanding and practices towards a more scientific and ecological approach to forest management. His research efforts through the 1960 s and 1970 s contributed to the implementation of sustainable approaches culminated in 1990 and 1993 with the production of two very influential documents for which Harvey was lead author: "A Silvicultural Guide for the tolerant Hardwoods Working group in Ontario" and "A TreeMarking guide for the Tolerant Hardwoods Working group in Ontario".
The Silvicultural Guide and Tree Marking guide provide "state of the art" information on tolerant hardwood silvics, silviculture, site growth and yield, wildlife considerations and prescription setting. The guides have been the principal reference manuals for industrial and government managers dealing with the tolerant hardwood forest in central and southern Ontario. Silvicultural ground rules developed and implemented through the Forest Management Planning Process for tolerant hardwood forest units across the Great Lake-St. Lawrence Forest Region must be consistent with the advice and direction in these guides.

Harvey continues to influence forestry through talks, nature walks and the production of Fact Sheets and papers He has developed an exceptional ability to put the science of our business in a usable format for both experts and the general public. His message is one that clearly indicates that good forestry is the result of good science, good planning and careful implementation.
A CIF/IFC Fellow is a member or ex-member of the Institute who has made outstanding contributions to the advancement of forestry or to the Institute, and may be elected a Fellow of the Institute by the CIF/IFC Board of Directors.

\section{New Director, Ecole des Garde \\ Forestiers}

Congratulations to Claude Chiasson on his recent appointment as Associate Director of the Ecole des Garde Forestiers in Bathurst. Claude will be replacing Rod O'Connell who retires in May, 2000.

Claude, who currently serves the NBFTA as First President and Chair of the Certification Board, was rewarded for his hard work, dedication \& professional attitude with the NBFTA Technician of the Year Award in 1997. No doubt these same qualities were recognized when the decision was made to choose Claude for this important position.

Best of luck Claude as you assume your new responsibilities!

\section{Information Technology}

\section{Integrated Taxonomic Information System}

Agriculture and Agri-Food Canada has just publicly launched the Canadian version of the Integrated Taxonomic Information System (ITIS-Ca). This comprehensive directory contains scientific and common names (French and English) for all known Canadian species, and places them within a taxonomic hierarchy. ITIS-Ca also provides an Internet Search Portal accessing Government of Canada (CanExplore) or global information holdings on these taxa.

The URL for ITIS-Ca is http://res.agr.ca/ itis.

Ole Hendrickson, Ph.D.

Science Advisor-Biodiversity

Science Branch

Canadian Forest Service

Natural Resources Canada

580 Booth St., 12th Floor

Ottawa, Ontario, Canada K1A OE4

phone (613) 947-9026 fax (613) 947-9035

ohendric@nrcan.gc.ca

\begin{tabular}{|c|c|}
\hline $\begin{array}{l}\text { The Fores } \\
\text { Editorial S }\end{array}$ & $\begin{array}{l}\text { Chronicle } \\
\text { redule } 2000\end{array}$ \\
\hline January/February & Millennium Edition \\
\hline March/April & The Urban Forest \\
\hline May/June & Open Forum \\
\hline July/August & $\begin{array}{l}\text { Forestry Chronicle } \\
\text { 75th Anniversary issue }\end{array}$ \\
\hline September/October & GIS/Remote Sensing \\
\hline November/December & $\begin{array}{l}\text { Annual Meeting } \\
\text { Theme Edition }\end{array}$ \\
\hline
\end{tabular}
To advertise in The Forestry Chronicle call Sue Easterman at (613) 234-2242
Deadline for the March/April issue: 15 February 